\title{
KAJIAN FURNITURE PADA RUMAH HUNIAN KOLONIAL BELANDA
}

\author{
Irena Vanessa Gunawan' ${ }^{1}$, Citra Amelia ${ }^{2}$ \\ Universitas Kristen Maranatha \\ 1irena.vgf@art.maranatha.edu, ${ }^{2}$ citra.amelia86@gmail.com
}

\begin{abstract}
Abstrak: Era Kolonisasi di Indonesia meninggalkan banyak pengaruh arsitektur dan interior. Selama bertahuntahun, penjajah terutama Belanda dan Inggris telah mengembangkan banyak bangunan arsitektur yang mencakup elemen interiornya. Bandung, adalah salah satu kota yang menikmati pengaruh besar desain kolonialisme Belanda. Namun perubahan cara hidup orang dan melakukan bisnis, mengubah perencanaan wilayah kota. Sebagian besar area perumahan sekarang telah menjadi area komersial / bisnis. Area rumah disewakan atau dijual untuk disulap menjadi kantor, kafe, restoran atau seluruhnya dihancurkan menjadi bangunan baru. Masih ada bangunan tempat tinggal dari zaman ini yang dijaga tetap seperti itu. Baik oleh pemiliknya dan didukung oleh permohonan masyarakat yang dimaksudkan untuk melestarikannya sebagai bangunan bersejarah. Namun belum ada upaya untuk melestarikan elemen interior, terutama furnitur. Karenanya ada sedikit pengetahuan tentang pengembangan desain furnitur sebagai hasil dari budaya hidup periode ini. Yang tersisa sulit untuk dipelajari karena furnituer memiliki rentang hidup yang lebih pendek daripada bangunan sehingga bisa diubah, dipindahkan, atau dijual. Dan sementara itu furnitur baru dapat diperoleh. Oleh karena itu, penelitian ini bertujuan untuk mempelajari apa yang tersisa dari furnitur dari era kolonialisasi di rumah hunian paticular ini. Untuk mencoba mendokumentasikan dan menganalisis gaya dan pengaruh apa yang biasa disebut "Mebel Belanda" oleh pedagang barang antik Indonesia dan juga oleh orang-orang pada umumnya. Penelitian ini akan mencoba mencari tahu bagaimana dan mengapa gaya khusus ini masih ada melalui era kolonialisme di Indonesia harus dibandingkan dengan perkembangan gaya di dunia Eropa.
\end{abstract}

Kata kunci: furnitur, Indonesia, kolonial Belanda

\begin{abstract}
The era of Colonization in Indonesia left many architecture and interior influence. For many years, colonizers especially Dutch and English have developed many architectural building which included their interior elements. Bandung, is one of the cities which enjoyed massive influence of Dutch colonialism design. However the change of people way of living and conducting business, change the city area planning. Most of residential areas now have becoming commercial/business area. Houses area are being leased or sold to be transformed into offices, cafes, restaurant or being entirely demolished into new buildings. There are still residential buildings from this era which are being kept as it is. Either by the owner and endorsed by the appeals of communities intended to preserve them as historical buildings. However there are not yet efforts to preserve the interior elements, especially the furnitures. Hence there are little knowledge about the development of furnitur design as a result of living culture of this period. The ones left are difficult to study as furnituer has shorter life span than building so it could be already altered, moved or sold. And in the meantime new furnitures could be acquired.Hence, it is the intention of this research to study what is left of furnitur from colonialization era in this paticular residential house. To try to documents and analyze what style and influence the commonly called "Dutch Furniture" by Indonesian antique dealers and also by the people in general.. This research will try to find out how and why this particular style still exist through the colonialism era in Indonesia to be compared to the development of styles in the European world.
\end{abstract}

Keyword: furniture, Indonesia, Dutch kolonial

\section{PENDAHULUAN}

Masa penjajahan membawa pengaruh pada aspek kehidupan masyarakat Indonesia, baik aspek ekonomi, religi, seni dan filsafat, maupun arsitektur dan interior yang berkembang pada saat itu. Masa kolonial telah memberi pengaruh positif dalam perkembangan arsitektur kota, dan interior yang menyertainya. Dua bangsa yang cukup memberikan pengaruh adalah 
Belanda dan Inggris. Rentang waktu pendudukan Belanda yang cukup panjang mematangkan aplikasi desain arsitektur yang tertuang di pelbagai bangunan publik dan privat termasuk bangunan hunian. Sedangkan Inggris walau hadir dalam kurun waktu yang relatif singkat namun memberikan dampak signifikan terhadap perkembangan bangunan dan furnitur di Indonesia. Bangunan-bangunan ini masih banyak yang bertahan hingga saat ini. Baik yang masih digunakan maupun yang sudah beralih fungsi atau dalam kondisi kosong. Keberadaannya dilestarikan oleh pemilik atau melalui peraturan daerah yang ada, berkat himbauan komunitas seperti Bandung Heritage.

Bila bangunan arsitektur cenderung memiliki usia yang cukup lama hingga masih dapat dinikmati , tidak demikian dengan elemen interior yang terdapat di dalamnya. Elemen interior yang melekat pada bangunan seperti pelapis langit-langit, dinding atau lantai cenderung masih bertahan, walau sebagian besar telah diperbaiki dengan material yang baru, namun pada sebagian bangunan bentuk dan penggayaannya masih dapat terlihat. Tidak demikian dengan furnitur yang merupakan pendukung kegiatan di dalam kehidupan sehari - hari. Dikarenakan usia material yang lebih singkat, walau untuk bangunan kolonial rata-rata menggunakan bahan kayu yang cukup kuat misalnya kayu eboni (Diospyros ebenum, Diospyros celebica) yang berwarna hitam, juga kayu kalamander (Diospyros quaesita), amboina (Pterocarpus indicus), sonokeling (Dalbergia latifolia), satin (Chloroxylon swietenia), dan jati (Tectona grandis). (Pamungkas, 2002). Selama bangunan berdiri ada kemungkinan furnitur yang ada telah rusak sehingga telah mengalami perbaikan dengan modifikasi atau dipindah keluar dari bangunan tersebut. Sebaliknya furnitur baru dapat dibeli atau dibuat dengan model yang berbeda.

Namun demikian sangat menarik karena saat ini masih ditemukan furnitur-furnitur yang secara umum disebut sebagai "Furnitur Belanda" terutama oleh para pedagang furnitur antik dan orang Indonesia pada umumnya. Furnitur tersebut adalah furnituryang secara umum terbuat dari kayu jati dengan finishing berwarna coklat atau coklat tua yang cenderung memperlihatkan urat atau tekstur kayu. Salah satunya seperti tipe furnituryang masih ada di rumah hunian bergaya kolonial Belanda di jalan Hariangbanga no. 11 dengan pemilik alm. Ong Jan Goan. Dari usianya maka bangunan ini seharusnya sudah termasuk di dalam kategori bangunan konservasi. Rumah ini masih terdapat furnitur gaya kolonial dengan kualitas yang baik dan dalam kondisi terawat. Renovasi rumah yang dilakukan beberapa kali mengakibatkan dokumen-dokumen pendukung catatan sejarah dan bukti pembelian furniturtersebut hilang. Walaupun tidak memiliki dokumen pendukung namun dapat dipastikan dari wawancara dengan nara sumber yang merupakan anak dari pembeli rumah, bahwa furnitur yang ada di rumah tersebut telah berusia minimalnya lebih dari 60 tahun.

Pada penelitian ini peneliti melakukan penelitian untuk mengidentifikasi gaya yang ada pada furnitur tersebut sebagai langkah awal mengidentifikasi sejarah perkembangan penggayaan yang ada di Indonesia dikaitkan dengan perkembangan penggayaan yang ada terutama di dunia Barat.

Hasil penelitian ini diharapkan dapat memberikan sumbangan pemikiran bagi perkembangan ilmu kebudayaan, berupa furnitur interior bersejarah, untuk dilestarikan keberadaannya sebagai refleksi sejarah kebudayaan manusia, selain itu dapat memberikan sumbangan pemikiran bagi perkembangan ilmu desain interior umumnya dan furnitur pada bangunan hunian kolonial Belanda khususnya yang dapat dijadikan bahan tinjauan awal untuk melakukan penelitian serupa di masa yang akan datang. 


\section{Penggayaan Furnitur Kolonial yang Ada di Indonesia Pada Umumnya}

Tidak banyak sumber literatur yang mencatat secara pasti mengenai sejarah perkembangan furnitur di Indonesia. Dave van Gompel di dalam buku yang ditulis untuk membahas koleksi ebony furnitur di Museum Troppe di Belanda, menuliskan bahwa kebanyakan perangkat furnitur ini merupakan koleksi pribadi dari keluarga-keluarga Belanda ketika kembali dari Indonesia. Kebanyakan furnitur ini disumbangkan ke museum tanpa disertai penjelasan tentang asal usulnya.Jumlahnya pun terbatas karena biaya kargo yang sangat mahal pada masa tersebut sehingga orang cenderung membawa pulang barang-barang yang lebih mudah dibawa dan dianggap berharga seperti tekstil, teh atau porselen.

Selain itu salah satu hal menarik yang juga dibahas di dalam buku tersebut adalah bahwa para penduduk Belanda secara umum tidak mengetahui keberadaan furnitur ini, kecuali mereka yang tinggal di Indonesia. Hal ini menunjukkan betapa uniknya koleksi furnitur ini yang pada awalnya dibuat untuk meniru gaya furnitur di Eropa (Gompel, 2013). Proyek yang dikerjakan oleh museum Troppen ini memungkinkan para ahli melakukan penelitian terhadap konstruksi dan penelitian terhadap usia material. Data terakhir yang diketahui adalah furnitur-furnitur yang ditemukan pada abad ke 19 dibuat oleh para pengrajin dari keturunan Tionghoa.

Walau ditemukan furnitur-furnitur yang berasal dari abad-17, namun dibahas juga bahwa beberapa penelitian menemukan bahwa tidak ada penjualan furnitur di pasar umum. Pada masa tersebut, furnitur bukan merupakan barang yang umum diperdagangkan. Hal ini menunjukkan bahwa mungkin furnitur-furnitur tersebut dibuat secara lokal. Di masa itu furnitur, terutama kursi bukan merupakan budaya masyarakat tradisional Indonesia yang lebih sering menggunakan tikar bambu untuk duduk. Pada perkembangannya kursi diproduksi dan hanya digunakan pada situasi tertentu yang berhubungan dengan orang barat atau pejabat tinggi.

Pada tahun 1730 an "ebony furnitur" tidak lagi menjadi trend, digantikan dengan furnitur dari china. Hal ini didukung dengan adanya perjanjian dagang antara Belanda dengan Kanton. Abad 19 Daendles atau Raffles (Raeffels chair) pada masa ini lebih berkembang British Regency Styles dibanding kan French neo-clacisism styles dan Empire styles. Pada masa ini kebanyakan furnitur diimport dari Inggris. Setelah itu abad 19 terjadi pencampuran antara gaya Belanda, Inggris, China dan Indonesia. Gaya tertentu seperti Biedermeier (18201850) dan Willem III (1850-1890) mulai kembali berpengaruh.

Pembagian periodesasi perkembangan kolonial Belanda di Indonesia menurut Helen Jussup, yaitu:

\section{A. Karakteristik gaya kolonial tahun 1600 sampai tahun 1800-an (Renaissance, Baroque, dan Rococo)}

\section{1). Baroque}

Desain kursi pada zaman baroque terkesan formal dan penuh dengan ornamen. Fasilitasfasilitas duduk dibuat dengan skala besar dan memiliki bentukan garis-garis lurus. Berbeda dengan desain pendahulunya, desain furnitur baroque nyaman untuk digunakan. Pada sandaran dan tempat duduk kursi, digunakan material upholstery, permadani, brokat, dan velvet. Desain baroque dikatakan sebagai refleksi dari "Raja Matahari Perancis", yang merupakan personifikasi dari kemewahan dan keagungan. Setiap desain menekankan pada logika dan susunan. Secara bentukan dibuat berskala besar, formal, dan memiliki ornamen. Desain memiliki tujuan utama untuk memberi kesan mendalam. 


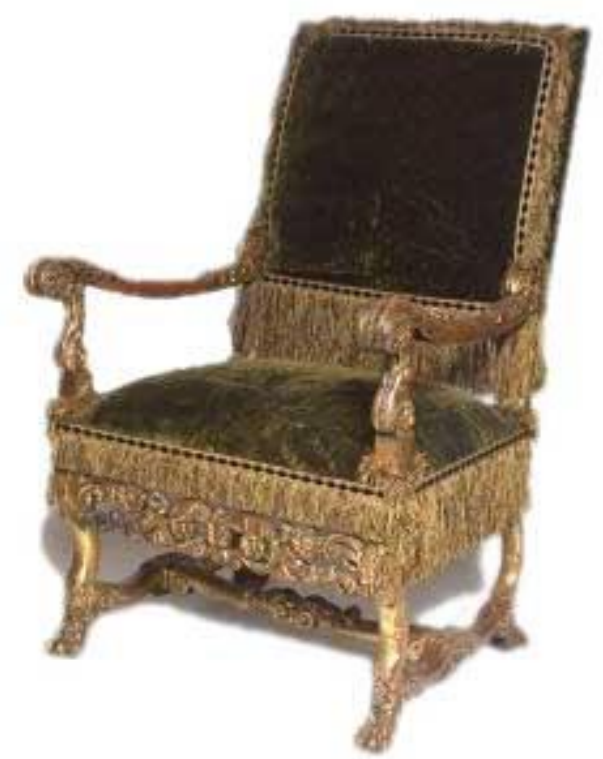

Gambar 1. Louis XIV Chair, 1675.

Sumber: http://www.furniturstyles.net/european/french/images/1675-louis-xivchair.jpg

Terdapat beberapa desain yang digunakan untuk ruang spesifik dengan posisi yang spesifik juga. Desain kaki furnitur mengalami perubahan dari awal baroque ke akhir baroque. Pada awal baroque, kaki furnitur berbentuk lurus dan dibubut atau dipahat berbentuk kotak. Di akhir baroque, kaki furnitur berbentuk cabriole tetapi berkesan besar. Kedua tipe desain baroque menggunakan jenis kayu ek dan walnut sebagai materialnya. Furnitur memiliki pahatan mewah dan disepuh. Seringkali furnitur dihiasi dengan lis-lis indah dan paku berlapis sepuh. Untuk penggunaan motif, furnitur dibubuhi dengan bentukan-bentukan klasik seperti satir, kerang, gulungan, emblem raja matahari, tanaman merambat dan topeng-topeng. Emblem raja matahari yang ditatah pada furnitur berbentuk seperti topeng yang dikelilingi oleh pendaran cahaya.

\section{2). Rococo}

Furnitur dibuat dengan skala yang lebih kecil dibandingkan dengan para pendahulunya. Kesan furnitur dibuat lebih ringan dan elegan. Desain dibuat dengan menggunakan lengkungan-lengkungan yang elegan. Pada era pemerintahan Louix XV muncul beberapa jenis furnitur baru seperti chiffoniers, meja tulis dengan ekstensi, meja untuk bermain kartu, meja roll-top, meja hias, kursi dengan lengan kursi yang pendek, dan escritoires. Pada era ini pula furnitur memiliki tempat-tempat persembunyian kecil yang dibuka dengan sistem pegas. Hal ini dikarenakan sifat masyarakat Perancis pada saat itu yang agak tertutup atau suka menyimpan rahasia.

Desain dipengaruhi oleh gaya hidup yang lebih nyaman, informal, dan intim. Bentukan mengadopsi lengkungan-lengkungan dan asimetris. Desain menekankan pada keharmonisan antara furnitur dengan interior sebagai satu kesatuan. Bagian kaki furnitur menggunakan desain cabriole yang lebih rumit. Ujung kaki berbentuk gulungan. Secara keseluruhan, bentukan furnitur berkesan memiliki banyak lengkungan. 


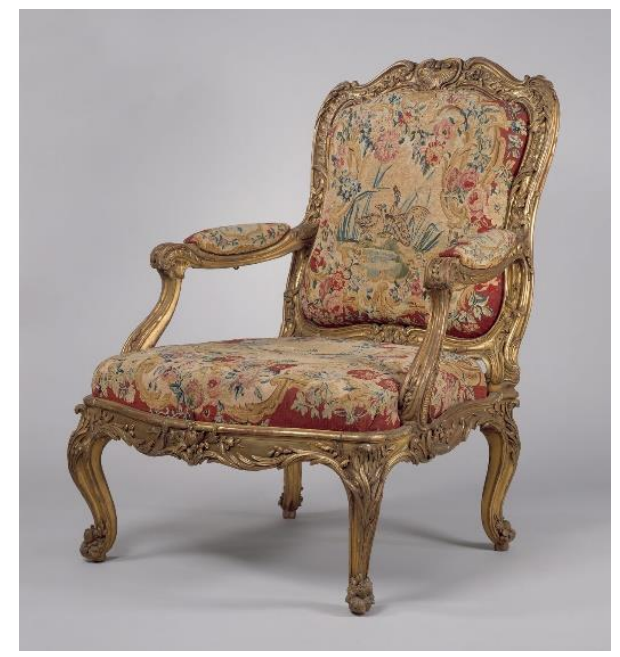

Gambar 2. Rococo Fauteuil Chair.

Sumber: http://www.timothy-corrigan.com/p/Louisxviconsole1.jpg

Ornamen yang digunakan pada desain furnitur berbentuk asimetris. Bagian dasar dudukan dan tatahan furnitur terbuat dari jenis-jenis kayu eksotis. Furnitur banyak difinishing menggunakan cat dan pernis China. Motif kerang-kerangan mendominasi hiasan furnitur. Selain kerang, motif yang digunakan juga adalah bentukan tanaman rambat yang natural, rocaille, gulungan berbentuk $\mathrm{C}$ dan $\mathrm{S}$. Gaya regence dan rococo juga menggunakan motif oriental sebagai hiasan dalam desain furnitur.

\section{B. Karakteristik gaya kolonial awal/Indische Empire tahun 1800-an sampai tahun 1900} (The Empire Style)

Di negara asalnya, Empire Style ini muncul pada tahun 1804-1830. Furnitur gaya empire menggunakan ikatan kuningan dan sepuhan. Untuk motifnya, banyak menampilkan daun salam, medali, rangkaian bunga berbentuk bundar, hiasan berbentuk mawar, emblem personal dari Napoleon: mahkota dan lebah. Gaya Empire didominasi warna merah karena merah dianggap mewakili Pompei namun juga menggunakan warna emas dan hitam dalam furniturnya.

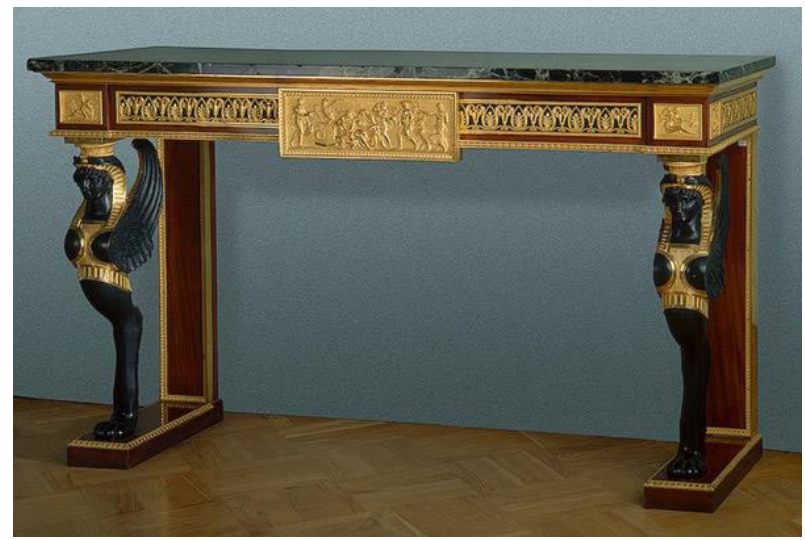

Gambar 3. Empire Console Table.

Sumber: http://www.timothy-corrigan.com/p/SecondEmpireTable.jpg 


\section{Karakteristik gaya kolonial modern/Nieuwe Bouwen tahun 1920 sampai 1940 (Gaya Indo-Eropa atau Landhuis dan Nieuwe Bouwen)}

\section{1). Elizabethan}

Furnitur Elizabethan memiliki banyak detail ornamental yang diukir. Bentukan banyak dibentuk menggunakan mesin bubut dengan bentuk kumparan ataupun bola. Material yang digunakan mayoritas adalah kayu ek dengan memakai sambungan mortise dan tenon. Secara general, furnitur pada era Elizabethan memiliki stretcher yang diletakkan sangat rendah hingga nyaris menyentuh tanah sebagai penopang kaki kursi. Kaki furnitur berkesan berat dan berbentuk bulat. Pada beberapa desain, kaki furnitur berbentuk melon bulb.

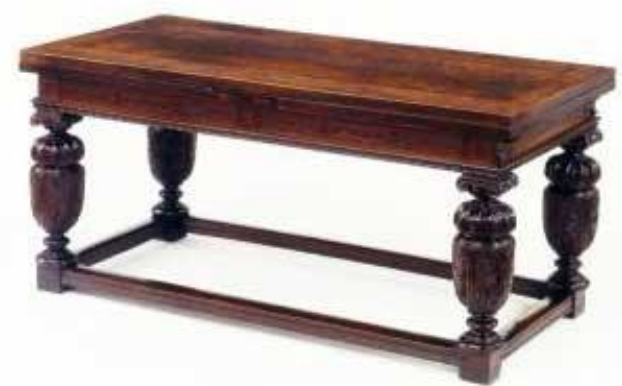

Gambar 4. Elizabethan Table.

Sumber: http://www.furniturstyles.net/european/english/misc/elizabethan-draw-table.jpg

Desain lengkungan berbentuk S dan C. Banyak terdapat ukiran tetapi relief yang dihasilkan tidak terlalu dalam. Dekorasi tidak hanya menggunakan ukiran tetapi juga menggunakan lukisan sebagai identitas Renaissance di Inggris. Motif yang sering digunakan pada furnitur Elizabethan adalah buah-buahan dan bunga, terutama buah anggur dan dahannya. Selain tanaman, desain Elizabethan juga menggunakan motif topeng, belah ketupat, dan beberapa bentukan fantasi. Gaya Elizabethan terlihat jelas dari 3 jenis desain fasilitas duduknya, yaitu kursi sambungan, kursi-X, dan kursi bubut.

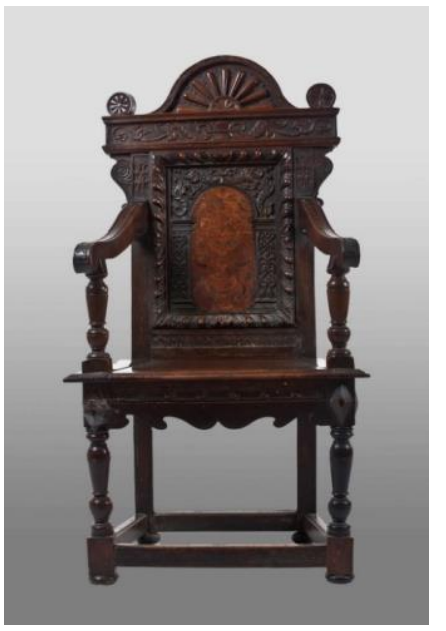

Gambar 5. Elizabethan Joined Walnut Great Chair, 1575.

Sumber: http://www.marhamchurchantiques.com/wp-content/uploads/KIM4101.jpg

Desain kursi sambungan Elizabethan merupakan penerus gaya Tudor era Wainscot. Bagian depan lengan kursi ditopang oleh baluster yang dibubut. Kaki kursi ditopang oleh stretcher yang diletakkan sangat rendah hingga nyaris menyentuh tanah. 


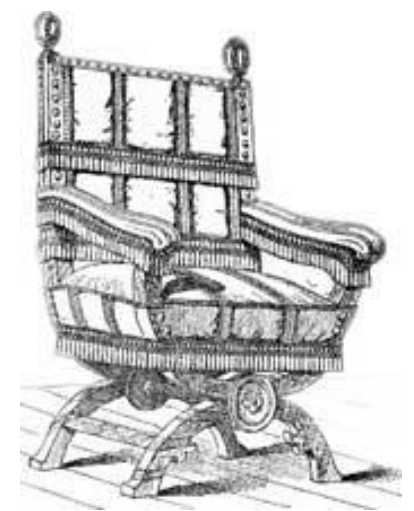

Gambar 6. Elizabethan X-Chair.

Sumber: http://www.furniturstyles.net/european/english/misc/elizabethan-X-framechair.jpg

Kursi lipat $\mathrm{X}$ dari gaya Elizabethan seringkali digunakan di kalangan bangsawan dan golongan masyarakat ekonomi atas. Kursi dilapisi oleh tekstil, seringkali menggunakan material velvet, dengan bagian tempat duduk merupakan rangkaian anyaman yang dapat menyerap beban tekanan. Biasanya kursi lipat X didesain satu set dengan sandaran kakinya.

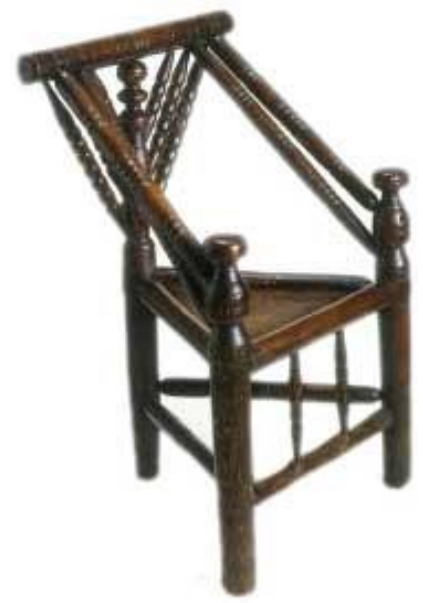

Gambar 7. Elizabethan Turned Chair.

Sumber: http://www.furniturstyles.net/european/english/misc/1600-turned-chair.jpg

Selain kursi lipat dan kursi sambungan, era Elizabethan juga melahirkan desain kursi bubut. Namun kursi jenis ini tidak nyaman untuk digunakan. Kursi bubut terbuat seluruhnya dari material kayu. Secara ergonomi, kursi ini pendek dan kecil. Kursi bubut adalah kursi yang diproduksi oleh tangan dengan cara memutar kayu pada mesin bubut. Karakteristik unik kursi ini terletak pada penopangnya yang hanya terdiri atas 3 buah kaki. Bagian sandaran kursi terdiri atas satu buah poros kayu besar dengan tiga buah poros kayu yang lebih kecil terletak di bagian kiri dan kanan poros utama.

\section{2). Jacobean}

Jacobean diambil dari nama Raja James I yang memerintah dari tahun 1603 - 1625. Fasilitas duduk era ini berkesan kokoh dan besar. Desainnya mengadaptasi desain Renaissance sampai desain Gothic namun dengan garis-garis yang lebih sederhana. Secara bobot dan bentukan memiliki skala yang lebih kecil daripada desain furnitur Elizabethan. 


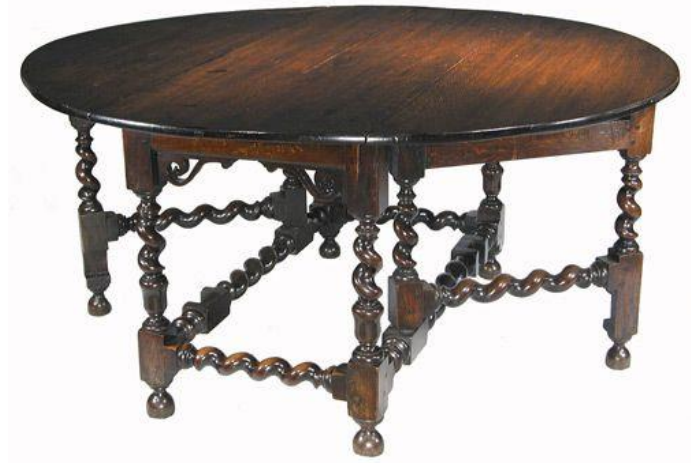

Gambar 8. Jacobean Table.

Sumber: http://www.timothy-corrigan.com/p/B/Jacobean.jpg

Menggunakan banyak ukiran pada desainnya. Material yang lazim digunakan adalah kayu ek dan walnut. Bagian kaki-kaki kursi terlihat seperti kolom kecil, beberapa berkesan seperti kolom kerdil. Bentuknya terbagi menjadi lurus atau spiral. Bentuk ini didapat dari sistem bubut yang akhirnya membentuk pola kumparan atau belitan spiral. Desain Jacobean seiring dengan waktu menjadi lebih sederhana pada aspek ornamennya dan semakin tidak menggunakan dekorasi.

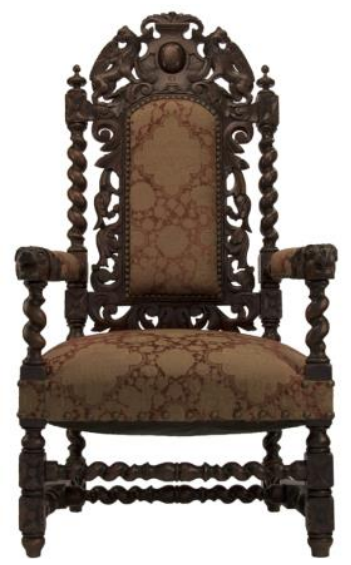

\section{Gambar 9. Jacobean Chair.}

Sumber: https://userscontent2.emaze.com/images/4be6dc5e-a4d5-4741-a4ea164aa354cb74/413fb86aa35e547189b851b0255d143b.jpeg

\section{3). Carolean}

Berlangsung pada masa pemerintahan Charles II. Penekanan utama desain ada pada kemewahan, kenyamanan, dan kenyamanan praktis.

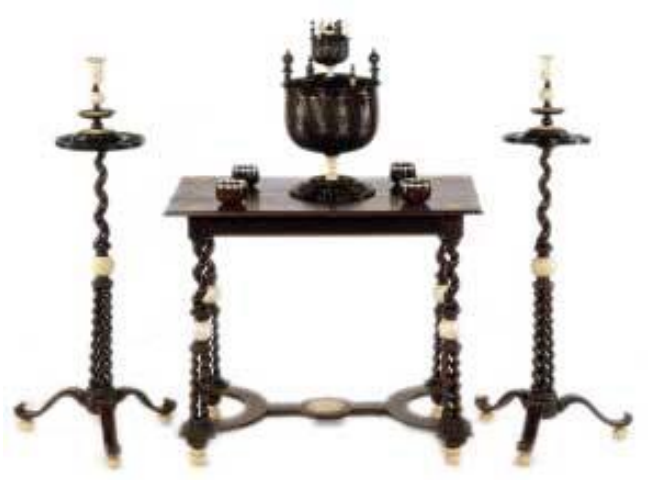

Gambar 10. Carolean Table Set.

Sumber: http://www.furniturstyles.net/european/english/misc/1670-table-set.jpg 
Sama seperti pendahulunya, gaya Carolean masih banyak menggunakan bentukan bubut spiral. Kaki kursi kayu berbentuk pilinan dan dinamakan sebagai sugar barley twist. Material kayu yang umumnya digunakan adalah kayu walnut. Stretcher pada gaya Carolean memiliki variasi pilinan. Kaki furnitur cabriole dengan bentukan kurva $S$ mulai muncul dan populer di zaman ini.

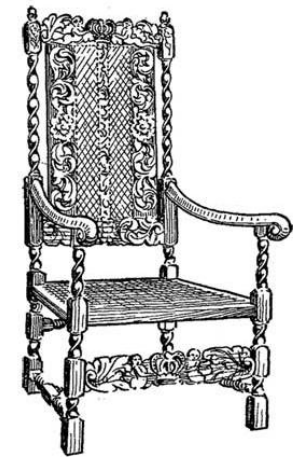

Gambar 11. Charles II Chair with Crown Emblem Carved in Back. Sumber: http://www.periodfurnitur-carved.co.uk/history/part5/history-2.htm

\section{METODE PENELITIAN}

Penelitian ini bersifat kualitatif dengan menggunakan pendekatan deskriptif. Selain itu, pendekatan exploratory studi kasus pada . Rumah tinggal Jl. Hariangbanga no. 11, yang dibangun 190 juga akan digunakan sebagai bagian dari proses analisis penelitian yang bersifat kualitatif. Rumah tinggal ini memiliki berbagai furnitur yang berasal sejak bangunan ini dibangun pada tahun 1908. Untuk membatasi keragaman pada furnitur yang ada, penelitian ini hanya difokuskan pada tipe fasilitas duduk dan meja.

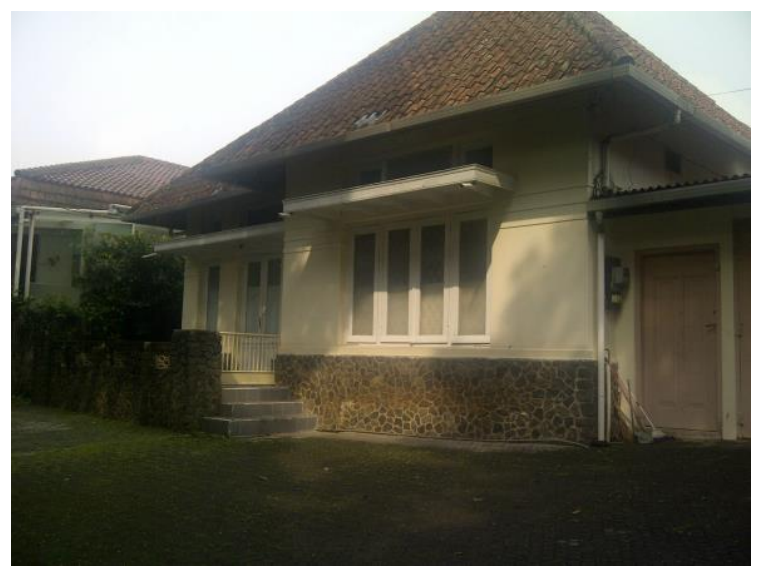

Gambar 12 . Rumah tinggal Jl. Hariangbanga no. 11, dibangun 1908

\section{HASIL PENELITIAN}

\subsection{Fasilitas duduk}

Fasilitas duduk atau kursi yang terdapat pada rumah tinggal Jln Hariang Banga no 11 terdiri atas beberapa jenis seperti yang akan dijabarkan di bawah ini. 


\section{1.a. Kursi tanpa lengan (1)}

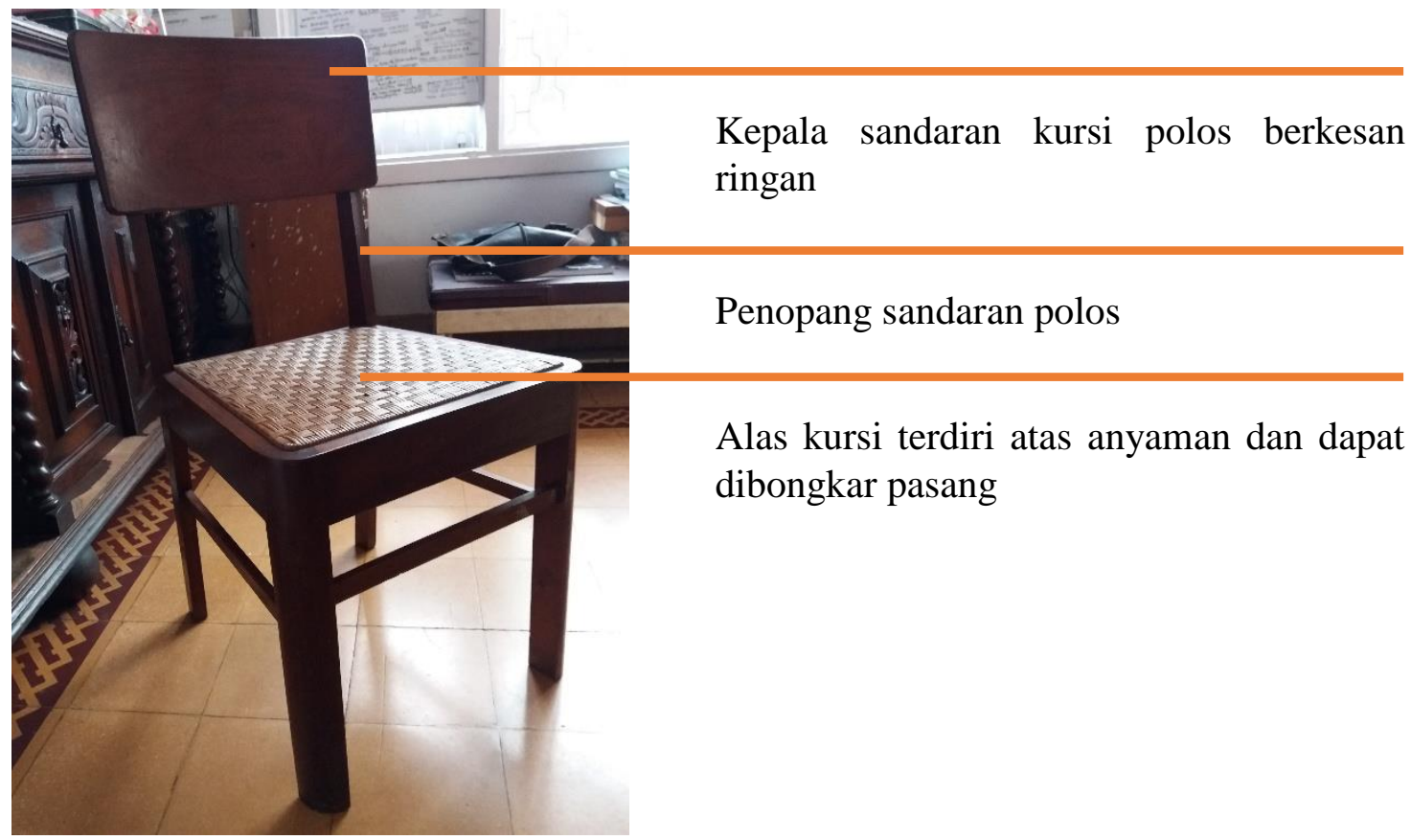

Gambar 13. Kursi Ruang Makan tanpa Lengan (1)

Kursi tanpa lengan ini berfungsi sebagai kursi meja makan. Desain kursi terkesan modern dengan tidak adanya ukiran yang menghiasi kursi. Bagian tempat duduk kursi menggunakan anyaman rotan yang dapat dilepaskan dari rangka kursi.

Bila diperhatikan lebih lanjut, seperti furnitur kolonial lainnya, kursi ini tidak menggunakan konstruksi sejenis sambungan biskuit untuk mempertahankan bentuknya.

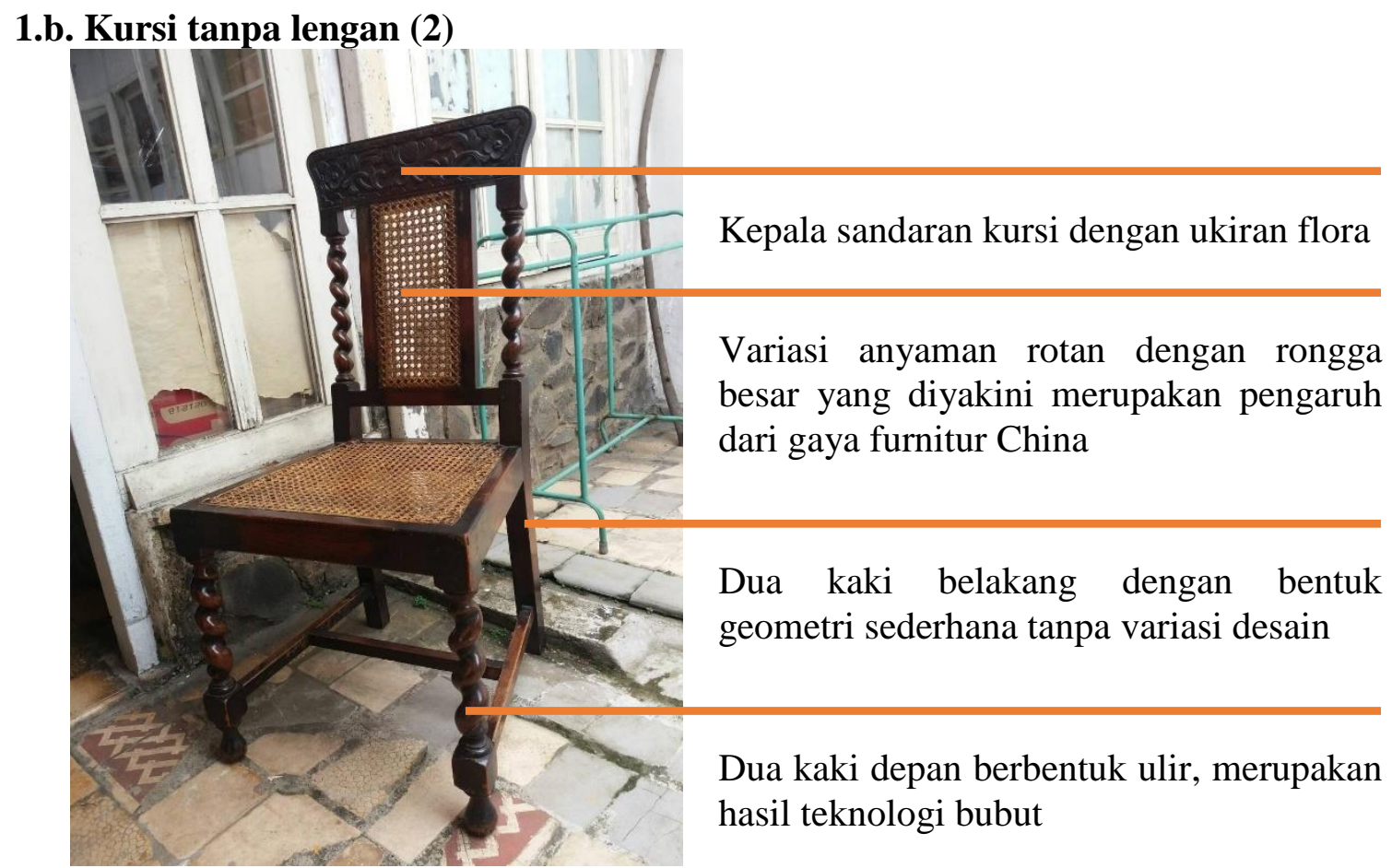

Gambar 14. Kursi tanpa Lengan (2) 
Berbeda dengan kursi dengan lengan yang telah dideskripsikan di atas, desain pada kursi tanpa lengan tipe II ini lebih terlihat bergaya klasik. Pada bagian atas sandaran kursi, terdapat ukiran berbentuk tanaman. Bagian tengah sandaran terbuat dari material rotan yang diframe oleh kayu. Bagian kiri dan kanan sandaran kursi terdapat penopang berbentuk spiral. Bentuk spiral ini juga muncul pada bagian kaki kursi bagian depan. Kaki kursi disambungkan satu sama lain dengan stretcher yang letaknya nyaris menyentuh tanah.

\section{1.c. Kursi dengan lengan}

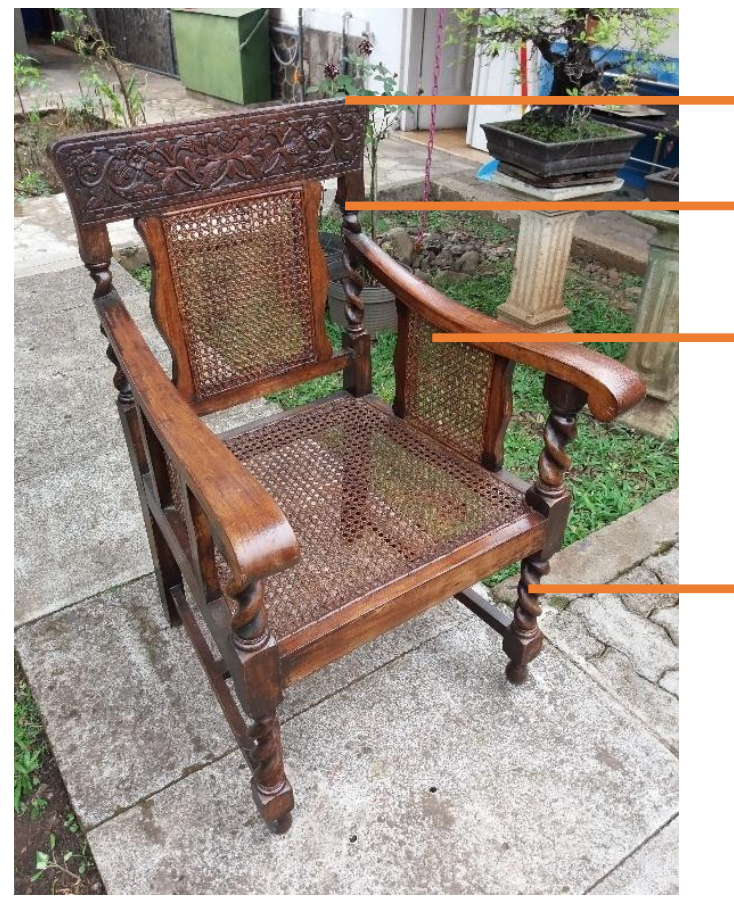

Kepala sandaran kursi dengan ukiran flora

Pangkal lengan kursi berbentuk ulir

Lengan kursi dengan variasi anyaman rotan pada bagian tengah ditopang oleh tiang berbentuk ulir pada bagian depannya

\section{Gambar 15. Kursi dengan Lengan}

Kursi dengan lengan ini merupakan variasi dari kursi tanpa lengan tipe II. Perbedaan pada kedua kursi terletak pada keberadaan armrestnya. Armrest berbentuk semi-organis dengan penopang berbentuk spiral pada bagian ujung armrest. Sedangkan pada bagian tengah armrest ditopang oleh anyaman rotan dengan frame kayu pada kedua sisinya.

\section{1.d. Sofa ruang keluarga}

Sofa ruang keluarga ini terdiri atas dua jenis seat, yaitu: sofa 1 seat dan sofa 2 seat. Namun secara desain, keduanya memiliki desain yang identik. Cushion sofa terbuat dari material busa keras yang dilapisi oleh leather berwarna merah marun.

Pada bagian atas sandaran terdapat hiasan berbentuk tanaman yang umumnya terdapat pada furnitur bergaya klasik lainnya. Armrest sofa terbuat dari material kayu dan berbentuk organis. Pada bagian ujung terdepan dan tengah armrest, terdapat topangan bentuk spiral. Sofa set ini memiliki kaki-kaki berbentuk bulb. 

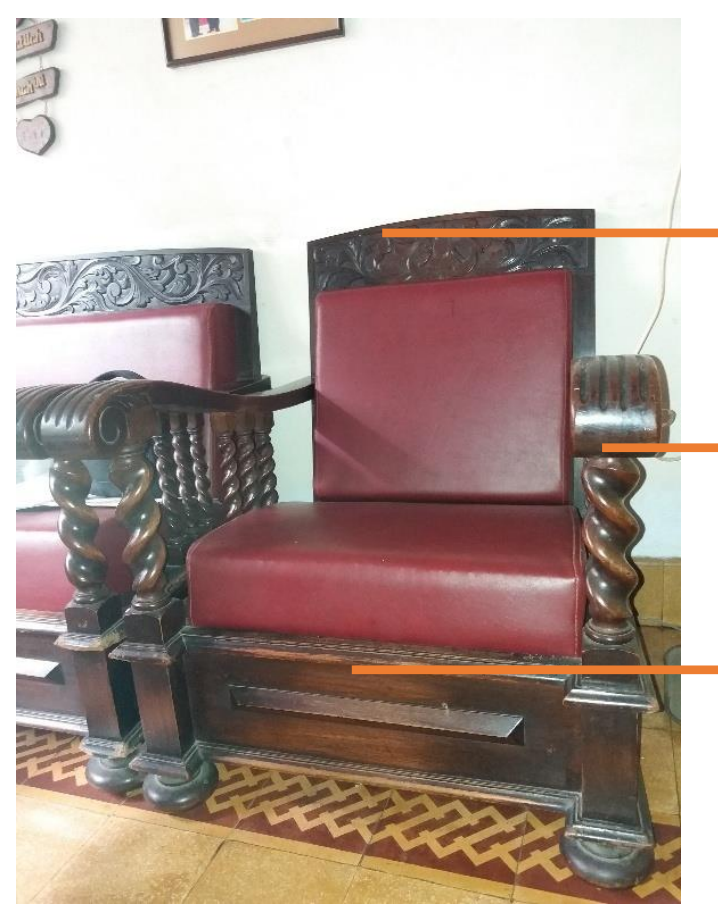

Kepala sandaran sofa dengan ukiran flora yang lebih sederhana dari ukiran pada kepala sandaran kursi

Lengan sofa memiliki desain organis namun tetap berkesan kokoh dan ditopang oleh tiang-tiang berulir

Bagian bawah sofa dibuat tanpa ukiran dengan kesan desain berat karena tertutup seluruhnya

\section{Gambar 16. Sofa Ruang Keluarga}

\subsection{Fasilitas Meja}

Meja yang terdapat di dalam set furnitur rumah ini terdiri atas meja makan dan coffee table. Keduanya berbentuk bundar dengan perbedaan pada sistem dan tipe kaki-kakinya.

Meja makan yang dikenal juga sebagai tipe meja besot ini berbentuk bundar. Meja dapat dibuka dan diperbesar bila diperlukan. Bagian kaki meja berbentuk spiral besar dan hanya terdiri atas satu kaki di bagian sentral meja.

\section{1.a. Meja makan}

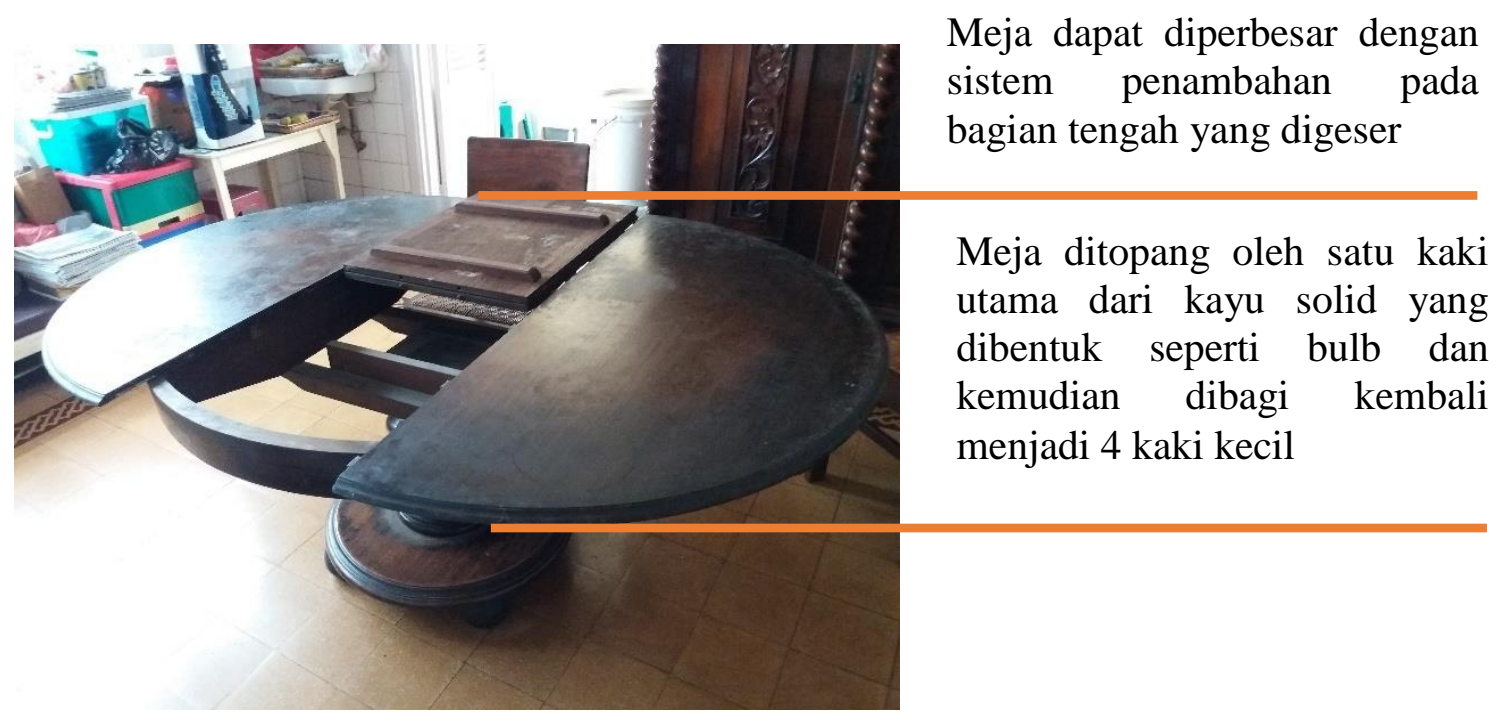

Gambar 17. Meja Makan 


\section{1.b. Coffee table}

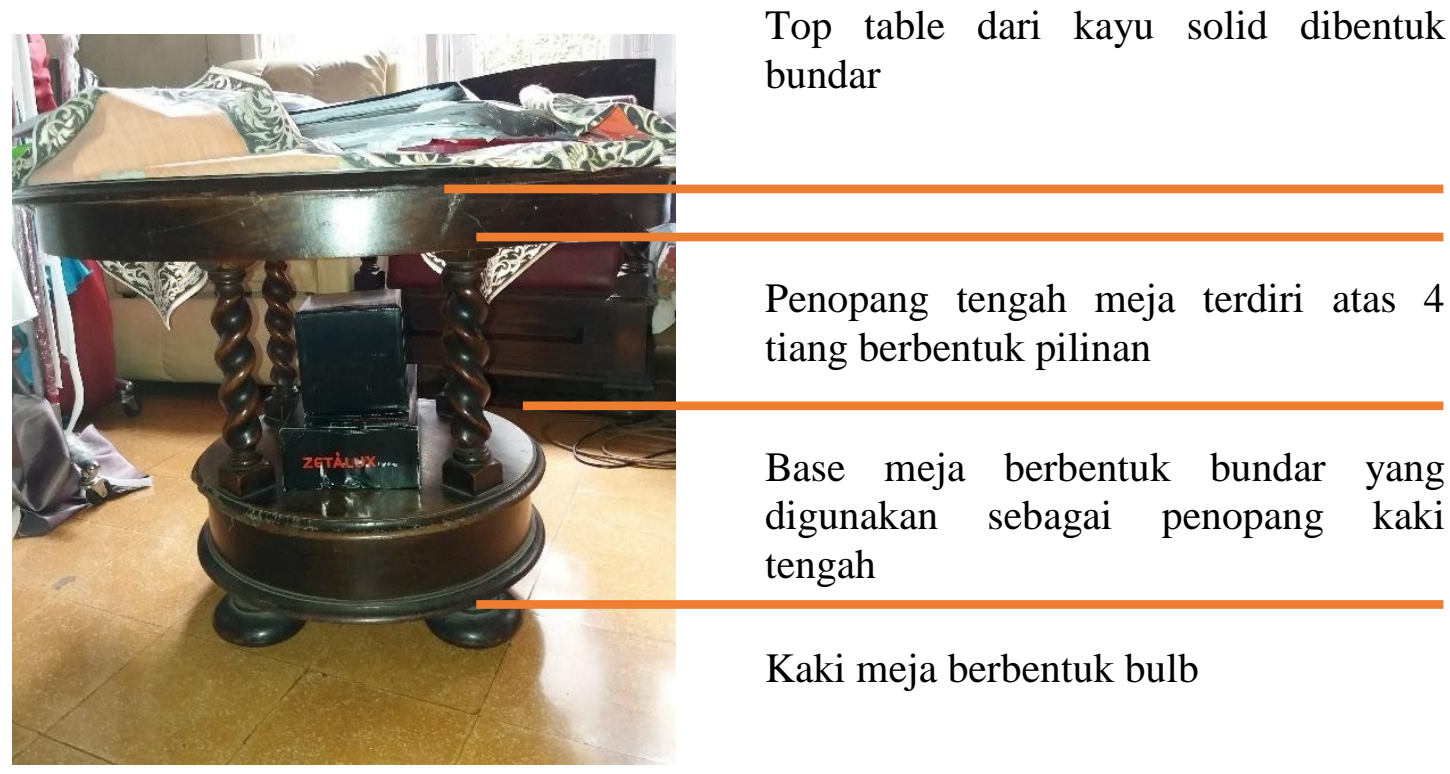

\section{Gambar 18. Coffee Table}

Coffee table ini masih memiliki gaya yang serupa dengan meja makan. Perbedaannya pada kaki penopang meja. Coffee table ini memiliki empat tiang penopang berbentuk spiral yang disatukan oleh bidang bundar di bagian bawahnya. Kaki meja berbentuk bulb dan terdiri atas empat buah.

\section{DISKUSI/PEMBAHASAN}

Dari pembahasan dapat disimpulkan bahwa penggayaan furnitur yang saat ini berada di $\mathrm{Jl}$. Hariangbanga no. 11 sangat dipengaruhi oleh penggayaan William dan Mary yang juga disebut periode early Baroque. Gaya ini merupakan gaya baroque yang telah mendapat berbagai pengaruh termasuk pengaruh China di dalam elemen-elemen anyaman rotannya. Gaya ini diklasifikasikan pada penggayaan furnitur Eropa yang berlangsung pada waktu yang kurang lebih sama dengan furnitur kolonial Belanda.

Gaya ini muncul pada masa tahta William III dan Mary di Inggris pada tahun 1689-1702. Raja William III yang berasal dari House of Orange di Belanda mendorong banyak artisan Belanda untuk mengikutinya, bersama dengan berbagai pengungsi Huguenot dari Prancis yang sebelumunya bekerja di toko-toko desain dan pembuat lemari di London.

Gaya William \& Mary terpengaruh oleh Belanda. Terdapat peningkatan aspek kenyamanan dalam kursi gaya William \& Mary.

Selain terpengaruh oleh Belanda, kursi gaya William \& Mary juga terpengaruh oleh gaya Baroque dan penggayaan China. Ketiga pengaruh gaya tersebut kemudian dikombinasikan dengan gaya Carolean dengan penyederhanaan pada desainnya. 


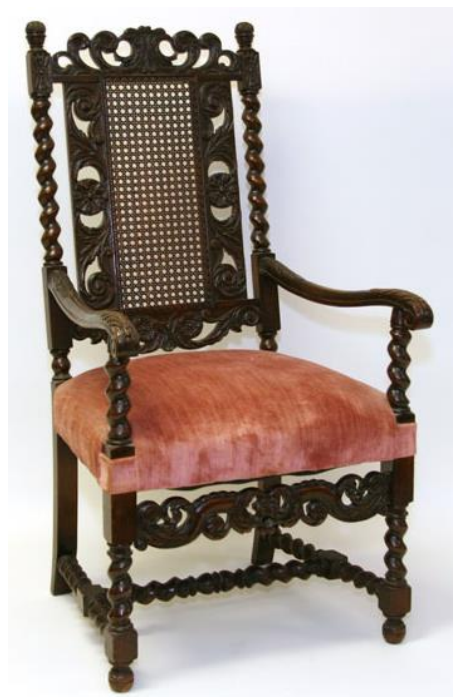

Gambar 19 . William and Mary Chair.

Sumber: http://antiquehelper.rfcsystems.com/Full/887/76887.jpg

Beberapa detail yang umum ditemukan pada desain kursi William \& Mary adalah:

- Desain sandaran kursi tertinggi daripada jenis kursi lainnya.

- Stretcher berbentuk kurva rangkap.

- Kaki seakan melenting ke arah belakang

- Ujung kaki berbentuk bulat seperti bola ataupun mengadopsi bentukan kuku hewan.

Lapisan veneering pada William \& Mary kebanyakan adalah pola yang rumit dari bentukan bunga. Untuk motif, gaya William \& Mary banyak mengambil bentuk scallop, kerang, daun ancathus, C-scrolls dan S-scrolls.

\section{KESIMPULAN}

Dari literatur dan pembahasan dapat disimpulkan bahwa penggayaan furnitur yang saat ini berada di Jl. Hariangbanga no. 11 sangat dipengaruhi oleh penggayaan William dan Mary yang juga disebut periode early Baroque. Gaya ini merupakan gaya baroque yang telah mendapat berbagai pengaruh termasuk pengaruh China di dalam elemen-elemen anyaman rotannya.

Hal ini sangat menarik mengingat gaya tersebut merupakan gaya yang berkembang di Inggris, yang walau periode penjajahan Inggris yang sangat singkat juga membawa pengaruh pada penggayaan furnitur kolonial di Indonesia. Minat terhadap ada gaya "kolonial" ini begitu kuat sehingga furnitur dengan gaya tersebut masih bertahan hingga seabad lebih. Pada studi kasus furnitur di bangunan hunian Hariangbanga no.11 diperlukan penelitian lebih lanjut untuk dapat memperkirakan usia furnitur tersebut, dan berharap ada lebih banyak lagi rumah kolonial yang dapat didokumentasikan furniturenya dalam kondisi lay out yang seasli mungkin. Dengan demikian juga dapat dipelajari mengenai pola hidup dan budaya masyarakat pada masa tersebut 


\section{DAFTAR PUSTAKA}

Gompel,D. 2013. Furnitur from the Netherlands East Indies 1600-1900: A Historical PerspectiveBased of the Collection of The Troppen Museum. KIT Publishers.

Gurr, King, Leon Straker, Phiilip Moore, 1998, "A history of Seating in the Western World", Ergonomics Australia 12, no. $3: 23-32$

Hayward, Charles, 2001, “Furnitur Industry”, Encyclopedia Britannica, www.britannica.com

Sari, Dian A., 2016 "Sejarah Mesin Bubut dan Perkembangannya", http://malahayati.ac.id/?p=18627

Christophe Pourny, Martha Stewart, Jen Renzi. 2014. The Furniture Bible. New York: Artisan

Foley, Edwin. 1911. The book of decorative furniture, its form colour \& history. London: T.C. E.C.Jack

Litchfield, Frederick. 1893. Illustrated History of Furniture, From the Earliest to the Present Time. London

Miller, Judith. 2005. Furniture. London: Dorling Kindersley Publishers Ltd

Pamungkas, G, 2002, "Bangunan Lama dan Mebel Masa Kolonial Belanda", Sumber: Harian Kompas, diunduh $27 \quad$ September 2017 dari :https://arsitekturindis.wordpress.com/2002/08/13/bangunan-lama-dan-mebel-masakolonial/

Wiryawan, M.R, "Tidak Selamanya Mantan itu Buruk : Perencanaan Kota Kolonial vs Modern", https://komunitasaleut.com/tag/bandoeng/, 29 Desember 2015. 